\title{
A Novel Mechanism of Glucocorticoid-induced Immune Suppression: The Inhibition of T Cell-mediated Terminal Maturation of a Murine Dendritic Cell Line
}

\author{
Toshiyuki Kitajima, Kiyoshi Ariizumi, Paul R. Bergstresser, and Akira Takashima \\ Department of Dermatology, University of Texas Southwestern Medical Center, Dallas, Texas 75235
}

\begin{abstract}
Working with the murine epidermal-derived dendritic cell (DC) line XS52, we have observed previously that antigenspecific interaction with $\mathrm{T}$ cells stimulates their "terminal maturation" into fully professional DC. In this study we examined the impact of dexamethasone (DEX) on this T cellinduced event. When added to cocultures of XS52 DC and the KLH-specific Th1 clone HDK-1 in the presence of antigen, DEX at relatively low concentrations $\left(10^{-9}-10^{-7} \mathrm{M}\right)$ prevented substantially or completely each of the changes that typify terminal maturation, including $(a)$ secretion of relatively large amounts of IL-1 $\beta$, IL-6, and TNF $\alpha$; $(b)$ loss of CD115 (colony-stimulating factor-1 receptor) expression and proliferative responsiveness to colony-stimulating factor-1; and (c) elevated expression of CD86 (B7-2). XS52 cells also underwent terminal maturation upon exposure to lipopolysaccharide alone, and DEX also inhibited effectively each of the same changes, indicating that DC can serve as the direct target of DEX. By contrast, DEX inhibited XS52 DC-stimulated IL-2 secretion by HDK-1 T cells, but not other changes that accompany $\mathrm{T}$ cell activation, including the secretion of IFN $\gamma$ and $\mathrm{TNF} \alpha$ and the elevated expression of CD25, CD28, and CD44. These results reveal a new immunosuppressive mechanism of glucocorticoid action, that is, direct inhibition of $\mathrm{T}$ cell-mediated terminal maturation by DC. (J. Clin. Invest. 1996. 98:142-147.) Key words: dexamethasone • IL-1 $\beta$ - CD28 • CD115 • CSF-1
\end{abstract}

\section{Introduction}

Glucocorticoids (GCs) ${ }^{1}$ have been used effectively for several decades as potent immunosuppressive agents in treating inflammatory diseases, including those that are mediated by $\mathrm{T}$ cells. With respect to pharmacological mechanisms of action, GCs are known to inhibit several immunologically relevant activities of monocytes and macrophages, including $(a)$ secretion

Address correspondence to Akira Takashima, M.D., Ph.D., Department of Dermatology, University of Texas Southwestern Medical Center, 5323 Harry Hines Blvd., Dallas, TX 75235. Phone: 214-6483419; FAX: 214-648-9292.

Accepted for publication 12 February 1996.

1. Abbreviations used in this paper: Ag, antigen; CSF-1, colony-stimulating factor-1; DC, dendritic cells; DEX, dexamethasone; GC, glucocorticoids; R, receptor.

J. Clin. Invest.

(C) The American Society for Clinical Investigation, Inc.

0021-9738/96/07/142/06 \$2.00

Volume 98, Number 1, July 1996, 142-147 of cytokines and prostaglandins; $(b)$ expression of surface receptors for complement and immunoglobulins; (c) phagocytosis and pinocytosis; and $(d)$ bactericidal and fungicidal activities. It is also known that GCs inhibit certain functions of $\mathrm{T}$ cells, including the secretion of IL-2, and their mitogenic potential. Based on these observations, the immunosuppressive activities of GCs have been attributed primarily to their influence on monocytes/macrophages and on T cells (1-4). On the other hand, extensive studies by Steinman and others have now established the concept that dendritic cells (DC), rather than macrophages and monocytes, are responsible for the initiation of $\mathrm{T}$ cell-mediated immunity (for review see reference 5). A critical question, then, concerns the impact that GCs have on DC, a question that has yet not been addressed, primarily due to the unavailability of stable DC lines for in vitro experimentation.

We have established recently long-term DC lines from the epidermis of newborn BALB/c mice (6). These lines, termed "XS series," retain important features of resident epidermal DC (Langerhans cells), including their surface phenotype (6), antigen (Ag)-presenting capacity $(6,7)$, and cytokine and cytokine receptor mRNA profiles (8-10). Working with these XS DC lines, we have observed that Ag-specific DC-T cell interaction delivers cell activation signals, not only forward to the responding T cells, but also back to the DC. More specifically, upon Ag-specific interaction with T cells, the XS52 cells (a) secrete relatively large amounts of IL-1 $\beta$ (11), IL-6, and $\mathrm{TNF} \alpha$ (Kitajima, T., and A. Takashima, unpublished observations); ( $b$ ) elevate their expression of CD86 (B7-2) (12); and (c) lose surface expression of CD115 (colony-stimulating factor-1 receptor [CSF-1R]) and proliferative responsiveness to CSF-1 (13). Incubation with $\mathrm{T}$ cells or Ag alone fails to induce any of these changes, indicating that each requires both $\mathrm{T}$ cells and Ag. These observations indicate that during Ag presentation bidirectional signaling events trigger a series of changes known as "T cell activation" and a second series of changes in the DC. Because IL-1 $\beta$, IL-6, TNF $\alpha$, and CD86 are all required for full activation of T cells, the induced changes in DC appear to represent their critical transition into fully professional Ag-presenting cells, a process that has been termed " $\mathrm{T}$ cell-mediated terminal maturation" $(11,13)$. Pharmacologic interference with this transition may serve as a method of suppressing T cell-mediated immune responses.

\section{Methods}

Cells. The XS52 line is a long-term DC line established from the epidermis of a newborn BALB/c mouse (6). This line has been expanded in growth medium consisting of complete RPMI supplemented with rGM-CSF (1-2 ng/ml) and culture supernatant ( $10 \% \mathrm{vol} / \mathrm{vol})$ collected from the NS01 or NS47 stromal cell line $(6,14)$. Features of the XS52 line have been described elsewhere (6-10). As responding T cells, we used the KLH-specific Th1 clone HDK-1 (15). The capacity 
of XS52 cells to activate this T cell clone has been described previously $(6,7)$.

Activation of DC and/or T cells. XS52 cells and HDK-1 T cells were cocultured in the presence of KLH $(100 \mu \mathrm{g} / \mathrm{ml})$ and then examined for cytokine secretion, phenotypic changes, and proliferative responses to CSF-1, as described before $(11,13)$. In some experiments, the XS52 DC and HDK-1 T cells were activated independently with LPS (20 ng/ml) and Con A $(4 \mu \mathrm{g} / \mathrm{ml})$, respectively (11). Dexamethasone (DEX) purchased from Sigma Immunochemicals (St. Louis, MO) was dissolved at $10^{-2} \mathrm{M}$ in ethanol and added to the above cultures at concentrations of $10^{-9}-10^{-6} \mathrm{M}$.

Cytokine assays. Culture supernatants were examined for IL-1 $\beta$, IL-2, IL-6, IFN $\gamma$, and TNF $\alpha$ with ELISA kits (Genzyme, Cambridge, MA), as described previously (11). Cytokine concentrations are shown in nanograms per milliliter as calculated from standard curves made with recombinant cytokines.

Flow cytometry. XS52 cells and HDK-1 T cells were readily distinguishable in $\mathrm{FACS}^{\circledR}$ by forward versus side light scatter, thus allowing us to characterize the surface phenotype of each cell type from a mixed population (13). Samples were stained with the anti-CD115 mAb 2E-11 (16), a generous gift from Dr. G. Gilmore (Western Pennsylvania Cancer Institute, Pittsburgh, PA) or with mAb against CD25, CD44, or CD86 (Pharmingen, San Diego, CA).

Proliferation assays. T cell-mediated changes in the proliferative responsiveness of XS52 cells to CSF-1 were examined as described previously (13). Briefly, XS52 cells $\left(1 \times 10^{4}\right.$ cells/well) were preincubated in 96-well plates for $24 \mathrm{~h}$ with $\gamma$-irradiated $(3,500 \mathrm{rad}) \mathrm{HDK}-1 \mathrm{~T}$ cells $\left(3 \times 10^{3}\right.$ cells/well $)$ in the presence of KLH. Subsequently, these cells were fed with $10 \mathrm{ng} / \mathrm{ml}$ of rCSF-1 (Gibco Laboratories, Grand Island, $\mathrm{NY})$ and then tested for $\left[{ }^{3} \mathrm{H}\right]$ thymidine uptake $5 \mathrm{~d}$ later.

\section{Results}

Impact of $D E X$ on cytokine secretion by $D C$. We detected relatively large amounts of IL- $1 \beta$, IL- 6 , and IFN $\gamma$ and modest amounts of IL-2 in supernatants collected from "complete" cocultures containing XS52 DC, HDK-1 T cells, and Ag (KLH) (Fig. 1, top). By contrast, none of these cytokines was detectable in significant amounts in supernatants collected from "incomplete" cocultures that lacked one or more of these components, indicating that all the three (DC, T cells, and Ag) are required for cytokine secretion. With respect to their source, we have observed previously that (a) IL- $1 \beta$ and IL- 6 are secreted primarily by XS52 DC; $(b) \mathrm{TNF} \alpha$ is secreted by both XS52 cells and HDK-1 T cells; and (c) IFN $\gamma$ and IL-2 are secreted exclusively by T cells (11) (Kitajima, T., and A. Takashima, manuscript in preparation). Importantly, when DEX was added continuously to the complete cocultures, the secretion of IL-1 $\beta$ and IL- 6 was inhibited in a dose-dependent manner, with significant inhibition at $10^{-9}-10^{-8} \mathrm{M}$ and nearly complete inhibition at $10^{-7}-10^{-6} \mathrm{M}$. DEX also inhibited, albeit partially, the secretion of TNF $\alpha$. Because of the relatively small amounts of IL-2, even in the absence of DEX, we were not able to study in a quantitative fashion the impact of DEX on its secretion. Nevertheless, in each of three independent experiments, IL-2 became undetectable when DEX was added at $10^{-9}-10^{-8} \mathrm{M}$. By contrast, DEX, even at the highest concentration of $10^{-6} \mathrm{M}$, had only a modest effect on the secretion of IFN $\gamma$.

Diminished secretion of DC-derived cytokines does not necessarily mean that DEX acts directly on the DC, because IL-1 $\beta$ secretion, for example, is triggered by coupling of surface class II and CD80/CD86 molecules (on XS52 cells) with their respective ligands (on HDK-1 cells) (11). DEX may have acted primarily on the $\mathrm{T}$ cells, inhibiting their expression of these ligands (i.e., the $\mathrm{T}$ cell receptor-CD3 complex and CD28/CTLA-4) and diminishing the secretion of IL-1 $\beta$ by DC. To determine whether DEX had acted directly on DC, we next stimulated XS52 cells with LPS in the absence of T cells. As

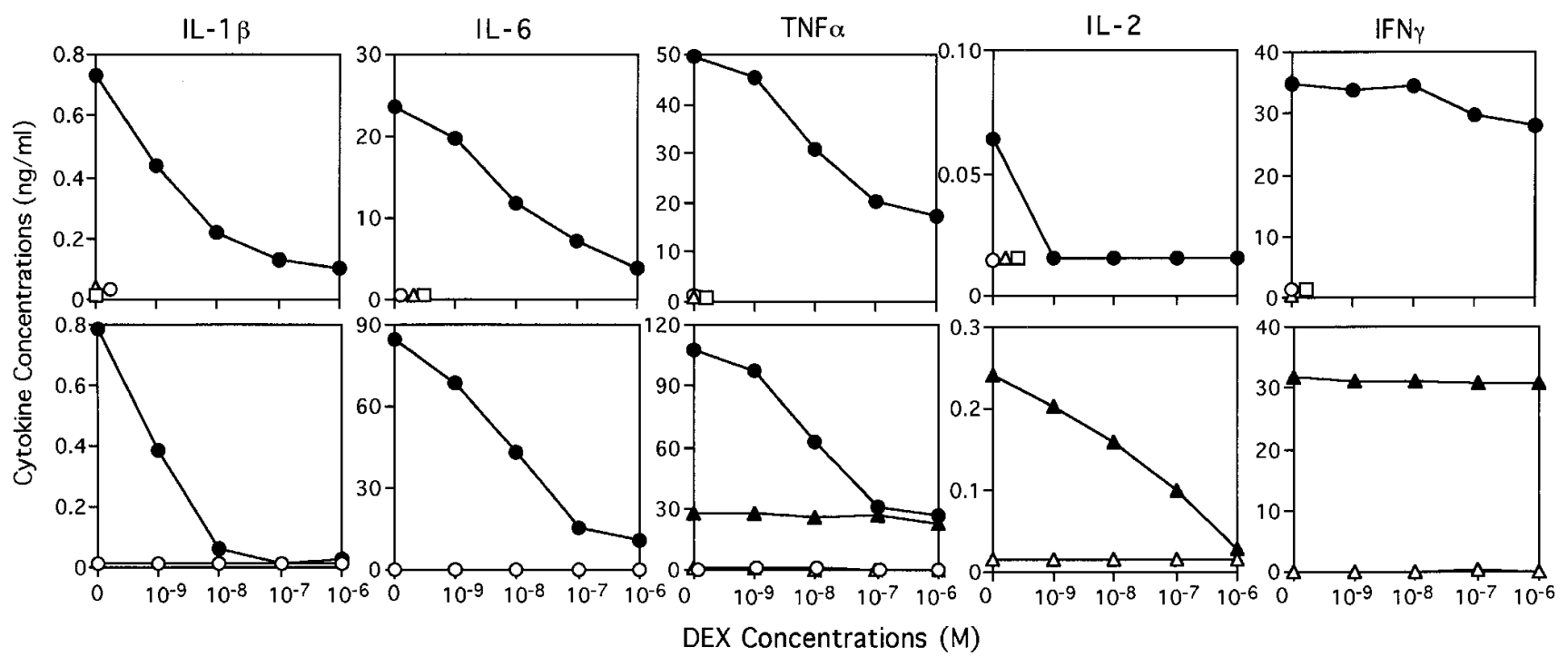

Figure 1. Impact of DEX on cytokine secretion by DC. (Top) XS52 cells $\left(5 \times 10^{5}\right.$ cells/ml) were cocultured for $24 \mathrm{~h}$ with HDK-1 T cells $\left(5 \times 10^{5}\right.$ cells $/ \mathrm{ml})$ and KLH $(100 \mu \mathrm{g} / \mathrm{ml})$ in the presence of the indicated concentrations of DEX (closed circles). Culture supernatants were then tested for the indicated cytokines by ELISA. As controls, we also tested culture supernatant collected from XS52/HDK-1 alone (open circles), XS52/ $\mathrm{KLH}$ alone (open triangles), or HDK-1/KLH alone (open squares). (Bottom) XS52 cells $\left(5 \times 10^{5}\right.$ cells $/ \mathrm{ml}$ ) were cultured for $24 \mathrm{~h}$ with $20 \mathrm{ng} / \mathrm{ml}$ of LPS (closed circles) or in its absence (open circles) in the presence of the indicated concentrations of DEX. Culture supernatants were then tested for IL-1 $\beta$, IL-6, and TNF $\alpha$. In some experiments, HDK-1 T cells $\left(5 \times 10^{5}\right.$ cells $\left./ \mathrm{ml}\right)$ were cultured for $24 \mathrm{~h} \mathrm{with} 4 \mu \mathrm{g} / \mathrm{ml}$ of Con A (closed triangles) or its absence (open triangles) in the presence of DEX. These culture supernatants were then tested for IL-2, IFN $\gamma$, and TNF $\alpha$. Data shown represent one set of results from three independent experiments. 

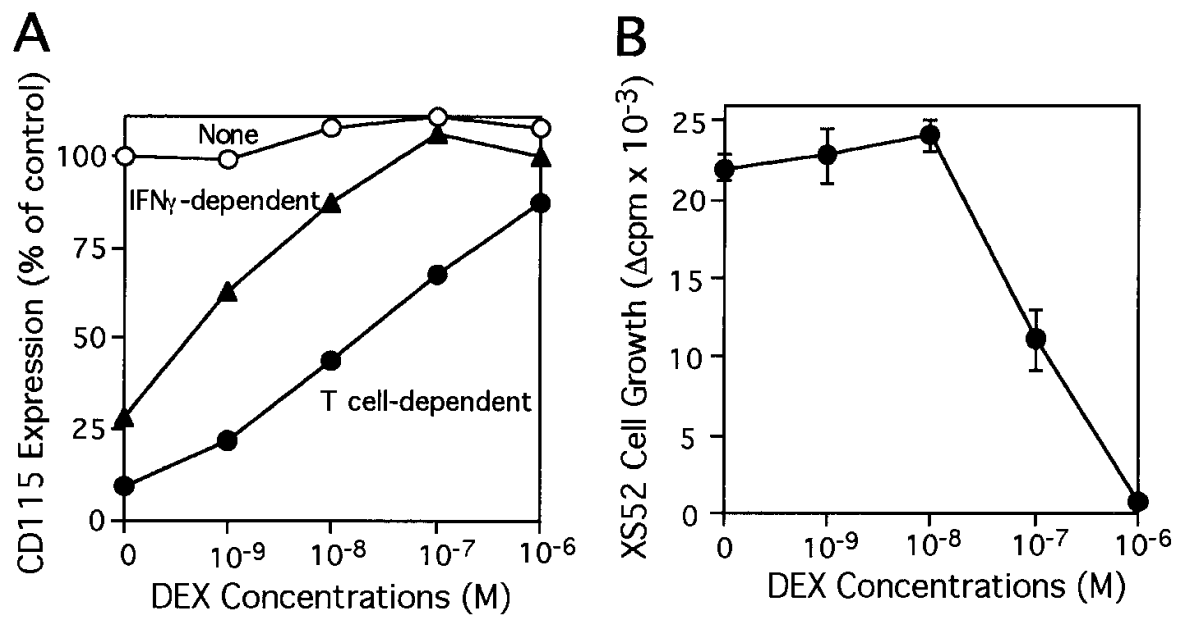

C

\section{HDK-1/KLH DEX}

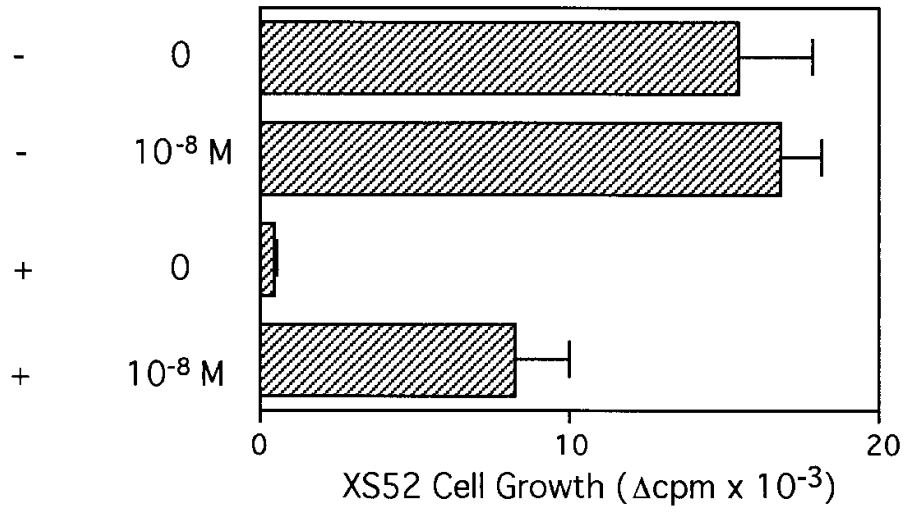

Figure 2. Impact of DEX on CD115 expression and proliferative responsiveness to CSF-1. $(A)$ XS52 cells $\left(2.5 \times 10^{5}\right.$ cells/ $\mathrm{ml})$ were cultured for $24 \mathrm{~h}$ in the presence (closed circles) or absence (open circles) of HDK- 1 T cells $\left(2.5 \times 10^{5}\right.$ cells $\left./ \mathrm{ml}\right)$ and KLH $(100 \mu \mathrm{g} / \mathrm{ml})$. Alternatively, XS52 cells were cultured for $24 \mathrm{~h}$ with $10 \mathrm{ng} / \mathrm{ml} \mathrm{rIFN \gamma}$ (closed triangles). DEX was added to these cultures continuously at the indicated concentrations. Samples were then stained with anti-CD115 $\mathrm{mAb}$ or an isotypematched control IgG, examined by FACS ${ }^{\circledR}$ after excluding HDK-1 T cells based on forward versus side light scatter. Data represent three independent experiments, showing the relative expression levels of CD115 calculated from the mean specific fluorescence intensity (intensity with antiCD115 minus intensity with control IgG). (B) XS52 cells $\left(1 \times 10^{4}\right.$ cells/well $)$ were examined for their proliferative responsiveness to $\mathrm{rCSF}-1(10 \mathrm{ng} / \mathrm{ml})$ in the presence of the indicated concentrations of DEX. (C) XS52 cells $\left(1 \times 10^{4}\right.$ cells/well $)$ were precultured for $24 \mathrm{~h}$ in the presence or absence of $\gamma$-irradiated HDK- 1 T cells $\left(3 \times 10^{3}\right.$ cells/well $)$ and $\mathrm{KLH}(30 \mu \mathrm{g} / \mathrm{ml})$ and then examined for their proliferative responses to $10 \mathrm{ng} / \mathrm{ml} \mathrm{CSF-1.} \mathrm{DEX} \mathrm{at} \mathrm{the} \mathrm{final} \mathrm{con-}$ centration of $10^{-8} \mathrm{M}$ was added throughout the incubation period. Data shown in $B$ and $C$ are the mean \pm SEM $(n=3)$ of CSF-1dependent $\left[{ }^{3} \mathrm{H}\right]$ thymidine uptake on day 5 , calculated as cpm in the presence of CSF-1 minus the baseline cpm in its absence. Each panel represents at least three independent experiments. noted in Fig. 1 (bottom), LPS-induced secretion of IL-1 $\beta$ and IL- 6 by the XS52 cells was inhibited by DEX in a dose-dependent fashion, once again, with significant inhibition at $10^{-9}$ $10^{-8} \mathrm{M}$ and almost complete inhibition at $10^{-7}-10^{-6} \mathrm{M}$. Moreover, LPS-driven secretion of TNF $\alpha$ by XS52 cells was inhibited almost completely. Thus, DEX can act directly on DC to inhibit the secretion of IL-1 $\beta$, IL- 6 , and TNF $\alpha$. When the HDK-1 $\mathrm{T}$ cells were stimulated with Con A (in the absence of DC), they secreted significant amounts of IL-2, IFN $\gamma$, and TNF $\alpha$. Although DEX inhibited IL-2 secretion effectively, only marginal, if any, inhibition was observed for the secretion of IFN $\gamma$ and TNF $\alpha$. Thus, the effect of DEX on cytokine secretion by $\mathrm{T}$ cells is relatively specific for IL-2.

Impact of DEX on CD115 expression and proliferative responsiveness to CSF-1. XS52 DC proliferate vigorously, not only in response to GM-CSF, but also to CSF-1 (9). Upon Agspecific interaction with HDK-1 T cells, however, they lose both their surface expression of CD115 (CSF-1R) and their proliferative responsiveness to CSF-1 (13). When DEX was added to complete cocultures of XS52/HDK-1/KLH, the XS52 cells retained their expression of CD115 (Fig. 2 A). In doseresponse experiments, $80 \%$ protection was achieved at $10^{-6} \mathrm{M}$. Treatment of the XS52 cells with IFN $\gamma$ alone was sufficient to abrogate CD115 expression, corroborating our previous report (13). Importantly, the IFN $\gamma$-induced downregulation of CD115 (in the absence of T cells) was also prevented by DEX, with complete protection obtained at $10^{-7} \mathrm{M}$. Thus, DC are a direct target of DEX for this effect as well.

A critical question then concerned whether DEX would allow XS52 cells to retain their proliferative responsiveness to CSF-1 after interaction with T cells. To address this question, we first identified DEX concentrations that would not inhibit XS52 cell growth directly; DEX up to $10^{-8} \mathrm{M}$ had only a modest effect, whereas above $10^{-7} \mathrm{M}$ it became inhibitory (Fig. 2 $B)$. Subsequently, DEX was added to the complete XS52/ HDK-1/KLH cocultures at concentrations below $10^{-7} \mathrm{M}$. In the absence of DEX, the XS52 cells lost their proliferative responsiveness to CSF-1 (Fig. 2 C). Importantly, DEX at $10^{-8} \mathrm{M}$ protected substantially (by $\sim 50 \%$ ) their proliferative responsiveness to CSF-1. In each of the three independent experiments, DEX $\left(10^{-8}\right.$ or $\left.10^{-9} \mathrm{M}\right)$ produced significant, albeit incomplete, protection of this activity. This most likely reflects the fact that DEX as high as $10^{-6} \mathrm{M}$ was required to preserve the full expression of CD115. Nevertheless, it is evident that DEX protects, at least partially, against $\mathrm{T}$ cell-dependent loss of proliferative responsiveness to CSF-1.

Impact of DEX on CD86 expression. As has been reported for epidermal DC (i.e., Langerhans cells) (17-20), from which the XS lines were established originally, XS52 cells constitutively express only negligible, if any, CD80 (B7-1) and CD86 

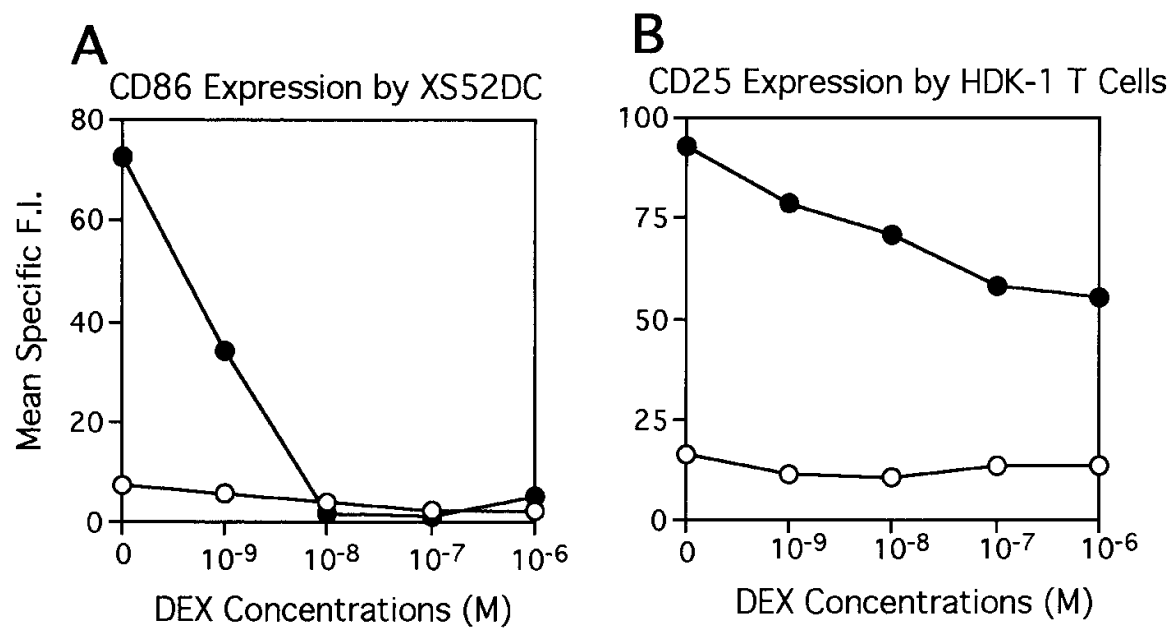

Figure 3. Impact of DEX on CD86 expression by DC. $(A) \mathrm{XS} 52$ cells $\left(2.5 \times 10^{5}\right.$ cells/ $\mathrm{ml})$ were cultured for $24 \mathrm{~h}$ in the presence (closed circles) or absence (open circles) of HDK- 1 T cells $\left(2.5 \times 10^{5}\right.$ cells $)$ and KLH $(100 \mu \mathrm{g} / \mathrm{ml})$. DEX was added to these cultures continuously at the indicated concentrations. Samples were then examined for CD86 expression by the XS52 cells. (B) HDK-1 T cells were cultured for $24 \mathrm{~h}$ in the presence (closed circles) or absence (open circles) of XS52 cells and KLH. These samples were then examined for CD25 expression by the HDK-1 cells. Data shown are the mean specific fluorescence intensity (intensity with a specific $\mathrm{mAb}$ minus intensity with a control $\operatorname{IgG}$ ), representing at least three independent experiments.

(B7-2) (6). However, they do increase the expression of CD86 upon Ag-specific interaction with HDK-1 T cells (Fig. $3 A$ ). Because ligation of CD28 (on T cells) with CD80/CD86 (on $\mathrm{DC}$ ) is required for maximal activation of $\mathrm{T}$ cells (for review see reference 21), this regulation represents a critical event in the maturation of DC into fully potent Ag-presenting cells. On the other hand, the responding HDK-1 T cells increase their expression of CD25, one component of the IL-2R complex, upon Ag-specific interaction with XS52 DC (Fig. 3 B). Therefore, both DC and T cells undergo critical phenotypic changes during Ag presentation. Importantly, DEX prevented, in a dose-dependent manner, CD86 induction in the XS52 cells, with a significant reduction at $10^{-9} \mathrm{M}$ and complete inhibition at $10^{-8} \mathrm{M}$. By contrast, DEX, even at higher concentrations (up to $10^{-6} \mathrm{M}$ ), inhibited CD25 induction in T cells only marginally.

To dissect further the differential influence of DEX on DC and T cells, we activated DC and T cells separately with LPS and Con A, respectively (Fig. 4). In response to LPS stimulation, the XS52 cells elevated CD86 and diminished CD115 expression, whereas the HDK-1 cells elevated their expression of CD25, CD28, and CD44. Importantly, DEX at $10^{-7} \mathrm{M}$ inhibited completely both CD86 upregulation and CD115 downregulation in the XS52 cells. By contrast, DEX at the same concentration had negligible, if any, effects on the expression of CD25, CD28, and CD44 by T cells. These results support our hypothesis that DC are a relevant target of DEX during Ag presentation.

\section{Discussion}

Our data demonstrate a novel mechanism through which GCs suppress $\mathrm{T}$ cell-mediated immunity, by preventing $\mathrm{T}$ cellmediated terminal maturation of DC. To recapture the es-
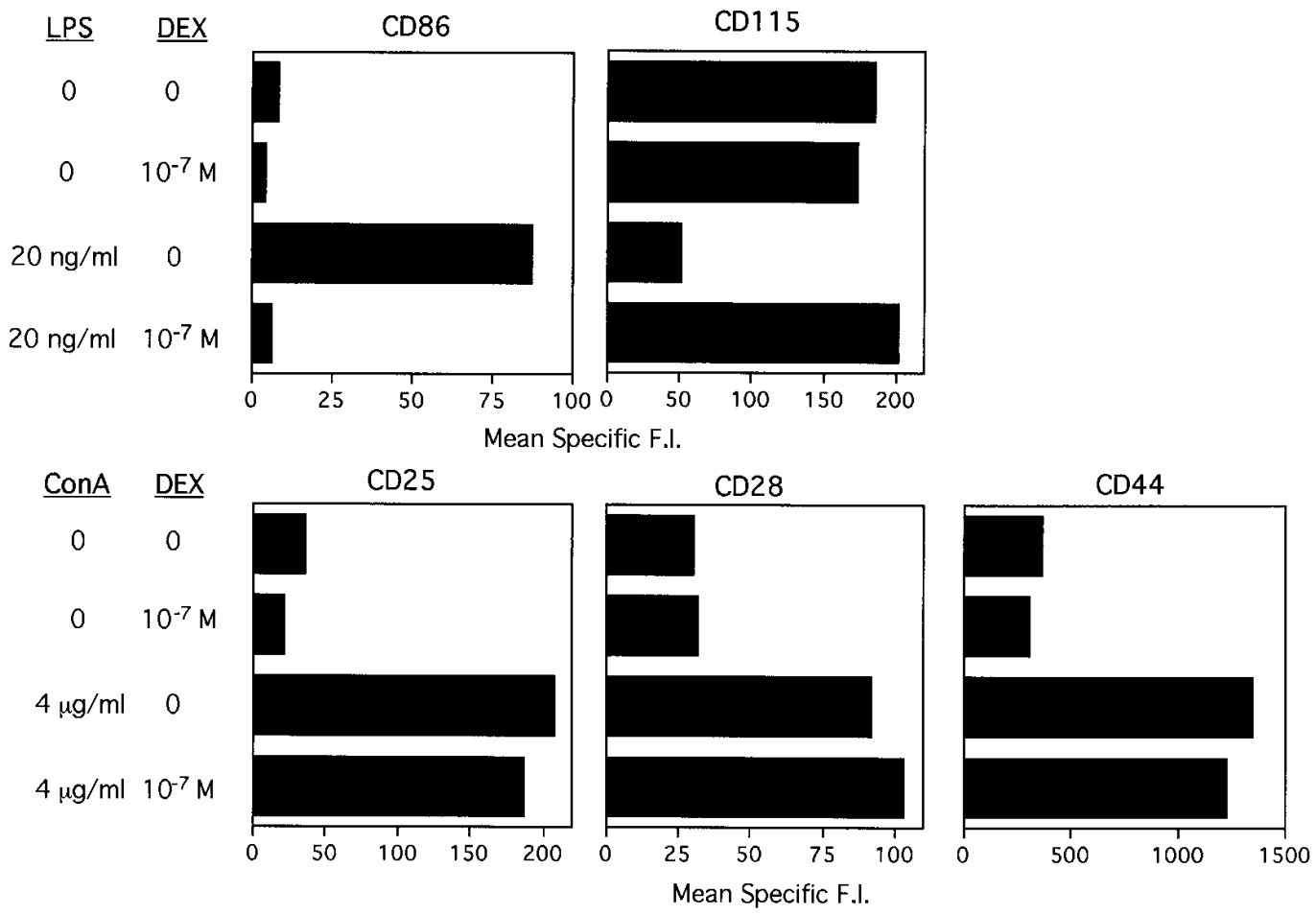

Figure 4. Differential impact of DEX on phenotypic changes of DC versus T cells. (Top) XS52 cells were cultured for $24 \mathrm{~h}$ in the presence or absence of LPS (20 ng/ml) and/or $\operatorname{DEX}\left(10^{-7} \mathrm{M}\right)$ and then examined for the expression of CD86 and CD115. (Bottom) HDK-1 T cells were cultured for $24 \mathrm{~h}$ in the presence or absence of Con A $(4 \mu \mathrm{g} / \mathrm{ml})$ and/or $\operatorname{DEX}\left(10^{-7} \mathrm{M}\right)$ and then examined for the expression of $\mathrm{CD} 25, \mathrm{CD} 28$, and CD44. Data shown are the mean specific fluorescence intensity (mean intensity with a specific $\mathrm{mAb}$ minus mean intensity with an isotype-matched control IgG). All the data represent at least three independent experiments. 
sence of our observations, the XS52 DC line undergoes, in response to Ag-specific interaction with $\mathrm{T}$ cells, a series of changes that includes $(a)$ secretion of IL- $1 \beta$, IL-6, and TNF $\alpha$; (b) loss of surface expression of CD115 (CSF-1R) and proliferative responsiveness to CSF-1; and $(c)$ heightened expression of CD86. Each of these changes was inhibited effectively and uniformly by DEX. By contrast, the influence of DEX on T cells was selective, inhibiting only IL-2 secretion, without affecting significantly other changes that accompany Ag presentation. Based on these observations, we conclude that DC are a relevant target of DEX.

The observation that DEX inhibits cytokine secretion by DC is not unexpected, given that GCs are known to downregulate the capacity of monocytes and macrophages to secrete IL-1 (22-25), IL-6 (26), and TNF $\alpha$ (27-29). However, our observation differs in several respects from these earlier reports. First, we have studied DC, which play an even more important role than monocytes and macrophages during the induction of primary $\mathrm{T}$ cell responses (5). Second, our experimental system uses Ag-specific interaction with $\mathrm{T}$ cells as a stimulus to trigger cytokine secretion, reflecting in vivo $\mathrm{Ag}$ presentation more closely than do other systems that use artificial stimuli, such as LPS or phorbol esters. In fact, the identity and biological relevance of each stimulus are especially important, because DEX has been reported to inhibit IL-1 $\beta$ secretion by LPS-stimulated monocytes but to augment IL-1 $\beta$ secretion triggered by phorbol myristate acetate (30). Finally, we have demonstrated that DEX differentially affects cytokine secretion by DC compared with T cells. The secretion of IL-1 $\beta$, IL- 6 , and TNF $\alpha$ by DC was inhibited uniformly by DEX, whereas its inhibitory effect on cytokine secretion by T cells was selective for IL-2. Even more strikingly, DEX inhibited DC, but not T cells, from secreting TNF $\alpha$. Taken together, these experiments document a new biological activity of DEX, i.e., the inhibition of T cellstimulated cytokine secretion by DC.

Our results provide new information with respect to mechanisms of GC action in suppressing T cell-mediated inflammatory diseases. Because IL- $1 \beta$, IL- 6 , and TNF $\alpha$ are all prototypic proinflammatory cytokines, interference with their secretion by DC is the most obvious mechanism. A second mechanism is derived from the diminished CD115 expression. Not only does the absence of CD115 abrogate the proliferative responsiveness of DC to CSF-1, it also may affect maturation. This is because GM-CSF and CSF-1 both promote the growth of XS52 cells, whereas only GM-CSF promotes maturation into potent Ag-presenting cells (8), and the loss of CD115 would make them selectively responsive to GM-CSF, thereby facilitating maturation. Thus, DEX-mediated protection of CSF-1 responsiveness serves as a second mechanism of immunosuppression by GCs. Finally, it is well established that CD80/CD86 (and perhaps other B7-related molecules) delivers critical costimulatory signals to $\mathrm{T}$ cells (21). In fact, antiCD86 mAb and CTLA4-Ig fusion proteins each block XS52 cell-dependent activation of HDK-1 T cells $(\mathrm{Xu}, \mathrm{S}$., and $\mathrm{A}$. Takashima, unpublished observations). Because XS52 cells, like resident epidermal DC, express only negligible, if any, CD80 and CD86, they must be acquired during Ag presentation to deliver $T$ cell activation signals. Thus, interference with the acquisition of CD86 is a third mechanism by which GCs may suppress $\mathrm{T}$ cell activation. Although the in vivo relevance of each of these pathways remains to be determined, this study provides a basis for the new concept that GCs suppress T cell- mediated immune responses by interfering with the terminal maturation of DC.

The proposed concept is mirrored in other reports. For instance, DEX has been shown to inhibit Ag-presenting celldependent activation of $\mathrm{T}$ cells, but not Ag-presenting cellindependent activation, as is triggered by phorbol esters and calcium ionophores (31). DEX is also known to downregulate the costimulatory capacity of Langerhans cells (32). More recently, DEX has been shown to downregulate the expression of CD80 and CD86 and to diminish the T cell stimulatory capacity by DC (33). It is also important to emphasize that this proposal does not conflict with the concept that DEX affects the function of $\mathrm{T}$ cells. As predicted by reports from many investigators $(31,34,35)$, DEX did inhibit IL-2 secretion by $\mathrm{T}$ cells in our experimental system. Although somewhat conflicting results have been reported with respect to the impact of GCs on the expression (and function) of the IL-2R complex (35-40), we observed that DEX had only a negligible effect on DC-stimulated expression of CD25 ( $\alpha$ chain). Importantly, DEX failed to inhibit the expression of CD28 or CD44 or to affect the secretion of IFN $\gamma$ or TNF $\alpha$. Thus, DEX does not inhibit all of the changes associated with $\mathrm{T}$ cell activation. It will be interesting to determine whether impaired maturation of DC (e.g., failure to secrete cytokines and express CD86) plays a causative role in DEX-sensitive changes (e.g., IL-2 secretion), but not DEX-resistant changes in T cells (e.g., secretion of IFN $\gamma$ ). Our experimental system will serve as a useful method to test this and other relevant questions regarding impact of GCs and other immunosuppressive drugs on Ag-specific DC-T cell interaction. Moreover, it may be possible to use this system to search for and to develop new compounds that inhibit DC maturation selectively.

\section{Acknowledgments}

The authors thank Dale Edelbaum for his technical assistance and Betty Janes for secretarial assistance.

This work was supported by National Institutes of Health grants R01 AR35068, R01 AR40042, R01 AR 41150, 1P30 AR41940, and by Mary Kay Cosmetics, Inc., the Dermatology Foundation, the Carl J. Herzog Foundation, the Lester I. Conrad Foundation, and The Perry R. and Nancy Lee Bass Research Fund in the name of Thomas L. Shields.

\section{References}

1. Russo-Marie, F. 1982. Macrophages and the glucocorticoids. J. Neuroimmunol. 40:281-286.

2. Munck, A., P.M. Guyre, and N.J. Holbrook. 1984. Physiological functions of glucocorticoids in stress and their relation to pharmacological actions. Endocr. Rev. 5:25-44.

3. Boumpas, D.T., F. Paliogianni, E.D. Anastassiou, and J.E. Balow. 1991. Glucocorticosteroid action on the immune system: molecular and cellular aspects. Clin. Exp. Rheum. 9:413-423.

4. Stam, W.B., A.J.M. Van Oosterhout, and F.P. Nijkamp. 1993. Pharmacologic modulation of Th1- and Th2-associated lymphokine production. Life Sci. 53:1921-1934.

5. Steinman, R.M. 1991. The dendritic cell system and its role in immunogenicity. Ann. Rev. Immunol. 9:271-296.

6. Xu, S., K. Ariizumi, G. Caceres-Dittmar, D. Edelbaum, K. Hashimoto, P.R. Bergstresser, and A. Takashima. 1995. Successive generation of antigenpresenting, dendritic cell lines from murine epidermis. J. Immunol. 154:26972705.

7. Caceres-Dittmar, G., K. Ariizumi, S. Xu, F.J. Tapia, P.R. Bergstresser, and A. Takashima. 1995. Hydrogen peroxide mediates UV-induced impairment of antigen-presentation in a murine epidermal-derived dendritic cell line. Photochem. Photobiol. 62:176-183. 
8. Xu, S., K. Ariizumi, D. Edelbaum, P.R. Bergstresser, and A. Takashima. 1995. Cytokine-dependent regulation of growth and maturation in murine epidermal dendritic cell lines. Eur. J. Immunol. 25:1018-1024.

9. Takashima, A., D. Edelbaum, T. Kitajima, R.K. Shadduck, G.L. Gilmore, S. Xu, R.S. Taylor, P.R. Bergstresser, and K. Ariizumi. 1995. Colonystimulating factor-1 secreted by fibroblasts promotes the growth of dendritic cell lines (XS series) derived from murine epidermis. J. Immunol. 154:51285135.

10. Ariizumi, K., T. Kitajima, P.R. Bergstresser, and A. Takashima. 1995. Interleukin- $1 \beta$ converting enzyme in murine Langerhans cells and epidermalderived dendritic cell lines. Eur. J. Immunol. 25:2137-2141.

11. Kitajima, T., K. Ariizumi, M. Mohamadzadeh, D. Edelbaum, P.R. Bergstresser, and A. Takashima. 1995. T cell-dependent secretion of IL-1 $\beta$ by a dendritic cell line (XS52) derived from murine epidermis. J. Immunol. 155:37943800 .

12. Ogoshi, M., T. Kitajima, S. Xu, P.R. Bergstresser, and A. Takashima. 1995. T cell-dependent activation of an epidermal dendritic cell line. J. Invest. Dermatol. 104:571a. (Abstr.)

13. Kitajima, T., K. Ariizumi, P.R. Bergstresser, and A. Takashima. 1995. T cell-dependent loss of proliferative responsiveness to colony-stimulating factor-1 by a murine epidermal-derived dendritic cell line, XS52. J. Immunol. 155:51905197.

14. Schuhmachers, G., S. Xu, P.R. Bergstresser, and A. Takashima. 1995. Identity and functional properties of novel skin-derived fibroblast lines (NS series) that support the growth of epidermal-derived dendritic cell lines. J. Invest. Dermatol. 105:225-230.

15. Simon, J.C., P.D. Cruz, P.R. Bergstresser, and R.E. Tigelaar. 1990. Lowdose UVB-irradiated Langerhans cells preferentially activate CD4 cells of the Th1 subset. J. Immunol. 145:2087-2091.

16. Shadduck, R.K., A. Waheed, K.F. Mangan, and C.S. Rosenfeld. 1993. Preparation of a monoclonal antibody directed against the receptor for murine colony-stimulating factor-1. Exp. Hematol. 21:515-520.

17. Inaba, K., M. Witmer-Pack, M. Inaba, K.S. Hathcock, H. Sakuta, M. Azuma, H. Yagita, K. Okumura, P.S. Linsley, S. Ikehara, et al. 1994. The tissue distribution of the B7-2 costimulator in mice. Abundant expression on dendritic cells in situ and during maturation in vitro. J. Exp. Med. 180:1849-1860.

18. Symington, F.W., W. Brady, and P.S. Linsley. 1993. Expression and function of B7 on human epidermal Langerhans cells. J. Immunol. 150:12861295.

19. Kawamura, T., and M. Furue. 1995. Comparative analysis of B7-1 and B7-2 expression in Langerhans cells: differential regulation by T helper type 1 and T helper type 2 cytokines. Eur. J. Immunol. 25:1913-1917.

20. Larsen, C.P., S.C. Ritchie, R. Hendrix, P.S. Linsley, K.S. Hathcock, R.J. Hodes, R.P. Lowry, and T.C. Pearson. 1994. Regulation of immunostimulatory function and costimulatory molecule (B7-1 and B7-2) expression on murine dendritic cells. J. Immunol. 152:5208-5219.

21. June, C.H., J.A. Bluestone, L.M. Nadler, and C.B. Thompson. 1994. The B7 and CD28 receptor families. Immunol. Today. 15:321-331.

22. Snyder, D.S., and E.R. Unanue. 1982. Corticosteroids inhibit murine macrophage Ia expression and interleukin 1 production. J. Immunol. 129:18031805 .

23. Lee, S.W., A.-P. Tsou, H. Chan, J. Thomas, K. Petrie, E.M. Eugui, and A.C. Allison. 1988. Glucocorticoids selectively inhibit the transcription of the interleukin $1 \beta$ gene and decrease the stability of interleukin $1 \beta$ mRNA. Proc. Natl. Acad. Sci. USA. 85:1204-1208.
24. Knudsen, P.J., C.A. Dinarello, and T.B. Strom. 1987. Glucocorticoids inhibit transcriptional and post-transcriptional expression of interleukin 1 in U937 cells. J. Immunol. 139:4129-4134.

25. Lew, W., J.J. Oppenheim, and K. Matsushima. 1988. Analysis of the suppression of IL- $1 \alpha$ and IL-1 $\beta$ production in human peripheral blood mononuclear adherent cells by a glucocorticoid hormone. J. Immunol. 140:18951902 .

26. Amano, Y., S.W. Lee, and A.C. Allison. 1993. Inhibition by glucocorticoids of the formation of interleukin- $1 \alpha$, interleukin-1 $\beta$, and interleukin-6: mediation by decreased mRNA stability. Mol. Pharmacol. 43:176-182.

27. Beutler, B., N. Krochin, I.W. Milsark, C. Luedke, and A. Cerami. 1986. Control of cachectin (tumor necrosis factor) synthesis: mechanisms of endotoxin resistance. Science (Wash. DC). 232:977-980.

28. Luedke, C.E., and A. Cerami. 1990. Interferon- $\gamma$ overcomes glucocorticoid suppression of cachectin/tumor necrosis factor biosynthesis by murine macrophages. J. Clin. Invest. 86:1234-1240.

29. Collart, M.A., D. Belin, J.-D. Vassalli, and P. Vassalli. 1987. Modulations of functional activity in differentiated macrophages are accompanied by early and transient increase or decrease in c-fos gene transcription. J. Immunol. 139:949-955.

30. Hume, M., P. Siljander, and H. Anttila. 1991. Regulation of interleukin-1 $\beta$ production by glucocorticoids in human monocytes: the mechanism of action depends on the activation signal. Biochem. Biophys. Res. Commun. 180:13831389.

31. Furue, M., Y. Kawakami, T. Kawakami, and S.I. Katz. 1990. Differential inhibition of the T cell activation pathway by dexamethasone and cyclosporine. Transplantation (Baltimore). 49:560-564.

32. Furue, M., and S.I. Katz. 1989. Direct effect of glucocorticosteroids on epidermal Langerhans cells. J. Invest. Dermatol. 92:342-347.

33. Moser, M., T. De Smedt, T. Sornasse, F. Tielemans, A.A. Chentoufi, E. Muraille, M. Van Mechelen, J. Urbain, and O. Leo. 1995. Glucocorticoids down-regulate dendritic cell function in vitro and in vivo. Eur. J. Immunol. 25: 2818-2824.

34. Arya, S.K., F. Wong-Staal, and R.C. Gallo. 1984. Dexamethasone-mediated inhibition of human $\mathrm{T}$ cell growth factor and $\gamma$-interferon messenger RNA. J. Immunol. 133:273-276.

35. Furue, M., and Y. Ishibashi. 1991. Differential regulation by dexamethasone and cyclosporine of human T cells activated by various stimuli. Transplantation (Baltimore). 52:522-526.

36. Fernandez-Ruiz, E., A. Rebollo, M.A. Nieto, E. Sanz, C. Somoza, F. Ramirez, A. Lopez-Rivas, and A. Silva. 1989. IL-2 protects T cell hybrids from the cytolytic effect of glucocorticoids. J. Immunol. 143:4146-4151.

37. Lamas, M., E. Sanz, L. Martin-Parras, E. Espel, P. Sperisen, M. Collins, and A.G. Silva. 1993. Glucocorticoid hormones upregulate interleukin 2 receptor $\alpha$ gene expression. Cell. Immunol. 151:437-450.

38. Reed, J.C., A.H. Abidi, J.D. Alpers, R.G. Hoover, R.J. Robb, and P.C Nowell. 1986. Effect of cyclosporin A and dexamethasone on interleukin 2 receptor gene expression. J. Immunol. 137:150-154.

39. Bloemena, E., M.H.J. Van Oers, S. Weinreich, and Th.A. Schellekens. 1988. Cyclosporin A and prednisolone do not inhibit the expression of highaffinity receptors for interleukin 2. Clin. Exp. Immunol. 71:308-313.

40. Paliogianni, F. S.S. Ahuja, J.P. Balow, J.E. Balow, and D.T. Boumpas. 1993. Novel mechanism for inhibition of human T cells by glucocorticoids. $J$ Immunol. 151:4081-4089. 